\title{
MOLECULAR STRATIFICATION OF SPORADIC AND HEREDITARY COLORECTAL CANCER -MINI REVIEW
}

\author{
Sanja Kapitanović \\ Laboratory for Personalized Medicine, Division of Molecular Medicine \\ Ruđer Bošković Institute, Zagreb, Croatia
}

\begin{abstract}
Summary
Colorectal cancer (CRC) is one of the most common cancers and one of the leading causes of cancer death in the Western world. The disease arises from the accumulation of mutations in oncogenes, tumor suppressor genes and mismatch repair genes during progression from normal colon epithelium to adenoma and metastatic carcinoma. The majority of colorectal cancers arise in sporadic form. About one-third of patients with CRC have a family history of cancer and elevated risk for this malignant disease. However, only 5\% of CRC arise from a germline mutation in high penetrant genes, adenomatous polyposis coli (APC) gene and DNA mismatch repair (MMR) genes. The most common hereditary CRC syndrome is Lynch syndrome defined by hereditary germline mutations in one the of MMR genes. The term hereditary non-polyposis colorectal cancer (HNPCC), previously used interchangeably with Lynch syndrome, now refers to a broader spectrum of familial CRC disorders that can mimic some clinical features of Lynch syndrome, but without germline mutations in MMR genes characteristic for Lynch syndrome. Distinguishing between the HNPCC disorders is important for clinicians, as the approach to surveillance for patients and their family members differs according to risk for CRC associated with each syndrome.

This mini review will give some information about the most frequent molecular genetics changes in sporadic and hereditary colorectal cancer and its molecular stratification due to its heredity, somatic mutations and microsatellite instability.
\end{abstract}

Keywords: colorectal cancer; sporadic; hereditary; microsatellite instability.

Colorectal cancer (CRC) is one of the most common cancers and represents the third most diagnosed cancer in both men and women. Despite advances in surgery, chemotherapy and screening it is still one of the leading causes of cancer related death in the Western world [1].

Of all human cancers, the molecular genetic alterations in colorectal cancer are best understood. The disease arises from the accumulation of mutations in oncogenes, tumor suppressor genes and mismatch repair (MMR) genes during progression 
from normal colorectal epithelium to adenoma and metastatic carcinoma (Figure 1) [2]. Colorectal cancer is a genetic disease that might be influenced by the local colorectal environment, individuals's genetic profile as well as by hereditary germline mutations $[3,4]$.

The majority of colorectal cancers (75-80\%) arise in sporadic form without known contribution from germline mutations and only $20-25 \%$ of the patients have a family history of CRC. However, only $5 \%$ of CRC arise from a germline mutation in high penetrant genes, adenomatous polyposis coli (APC) gene (1\%) and MMR genes (3-5\%) while the remaining CRCs have a positive family history but cannot be categorized to any hereditary CRC syndrome. These familial CRC are caused by single nucleotide polymorphisms (SNP) in less penetrant genes such as cytokines. Many susceptibility loci have been identified, however, their value in CRC risk prediction remains low $[5,6]$.

The development of colorectal cancer is a multistep process caused by progressive accumulation of genetic and epigenetic changes that cause activation of oncogenes and/or inactivation of tumor suppressor genes. The earliest trigger is the mutation of the APC (Adenomatous Polyposis Coli) gene. Mutations in oncogenes $(K R A S)$ and tumor suppressor genes $(p 53, D P C 4)$ as well as mutations and epigenetic changes in MMR (MisMatch Repair) gene drive tumor towards malignant transformation and metastasis. [3,5,7-9].

Sporadic CRC can be divided into two groups: hypermutated ( $16 \%$ of sporadic $\mathrm{CRC}$ ) and nonhypermutated ( $84 \%$ of sporadic CRC). The etiology of hypermutated tumors is largely driven by the presence of microsatellite instability (MSI) as a result of mutations in mismatch repair (MMR) genes, specifically somatic hypermethylation of hMLH1 gene. Nonhypermutated sporadic CRC is driven by mutations described as adenoma carcinoma sequence including APC, KRAS and p53 gene mutations. BRAF gene is most frequently mutated in hypermutated tumors than $A P C$ is mutated in both groups of sporadic CRC, what is in accordance with its role as a gatekeeper mutation in CRC [3,10-12]. The results of research studies also characterized 3 molecular pathways that highlight CRC development and progression: MSI (wholly within the hypermutated group), chromosomal instability (CIN; wholly in the nonhypermutated group) and CpG island methylator phenotype (CIMP; within both the hypermutated and nonhypermutated group) [3].

The level and nature of inflammation in primary CRC may be complex, but the type, density and intratumor location of immune cells can predict patient survival, often better than classical staging [13]. This same inflammation has been associated with initiating alterations involving specific tetranucleotide microsatellite DNA sequences, termed "elevated microsatellite alterations at selected tetranucleotide 
repeats" or EMAST caused by loss of the DNA MMR complex function due to a nucleus-to-cytosol shift of its component hMSH3 protein. EMAST can be identified in up to $60 \%$ of CRCs making this biomarker more common than MSI high (MSI-H) [14]. The presence of EMAST in primary CRCs predict advanced-stage disease in patients and is associated with poor survival over patients with EMAST negative CRC tumors. EMAST can modulate all 3 (MSI-H, CIN and CIMP) pathways in sporadic CRC tumorigenesis and is a biomarker linked to advanced, metastatic stage and poor survival in both groups, hypermutated and nonhypermutated sporadic colorectal cancer $[15,16]$.

About one-third of patients with colorectal cancer have a family history of cancer but only $5 \%$ of all patients with CRC have identified hereditary mutations in genes that regulate growth processes in colonic cells. The most common hereditary CRC syndrome is Lynch syndrome identified and defined by hereditary germline mutations in one of the DNA mismatch repair (MMR) genes (MSH2, MLH1, MSH6, PMS2) and is transmitted in an autosomal dominant fashion [17]. Mismatch repair proteins form a complex that detects and corrects replication errors. A deregulated MMR system due to the mutations in MMR genes leads to accelerated accumulation of somatic mutations, often resulting in carcinogenesis. The two most commonly mutated MMR genes, MSH2 and MLH1, account for approximately $90 \%$ of mutations found in Lynch syndrome patients, with the remaining $10-30 \%$ distributed equally in MSH6 and PMS2 [17-19].

Microsatellite instability (MSI) is the molecular marker of MMR genes mutations and DNA mismatch repair deficiency. Additionally, the use of immunohistochemistry to detect expression of DNA MMR proteins in tumor tissue is highly comparative to MMR function. The finding of MSI and/or absence of DNA MMR protein expression identifies that a tumor has lost DNA MMR function, and is the basis for differentiating familial CRC cases associated with Lynch syndrome from other HNPCC conditions [19-22].

The term hereditary non-polyposis colorectal cancer (HNPCC), previously used interchangeably with Lynch syndrome, now refers to a broader spectrum of familial CRC encompassing disorders that can mimic some clinical features of Lynch syndrome, but without germline mutations in MMR genes characteristic for Lynch syndrome. Distinguishing between the HNPCC disorders is important for clinicians, as the approach to surveillance for patients and their family members differs according to risk for colonic and extracolonic cancers associated with each syndrome $[18,19,23]$.

Lynch-like syndrome is HNPCC condition associated with CRC tumors with two somatic mutations in one of the MMR genes in the tumor, but no germline 
mutations. Although these cases are not hereditary, the tumors manifest MSI and immunohistochemically absence of a MMR protein. Limited published data suggests that Lynch-like syndrome patients have a similar age of onset of CRC but lower incidence of extra-colonic cancers compared to patients with Lynch syndrome [4,24].

Familial colorectal cancer type X (FCCTX) is HNPCC condition associated with CRC tumors negative for MSI and germline mutations in MMR genes. Clinically, FCCTX is associated with a twofold increased risk of CRC compared to the general population but without an increased risk of extra colonic cancers $[4,22,23]$.

Polymerase proofreading associated polyposis syndrome (PPAP) is a rare autosomal dominantly inherited syndrome in which the exonuclease domain of POLE (encoding DNA polymerase $\varepsilon$ ) or POLD1 (encoding DNA polymerase $\delta 1$ ) is mutated in the germline. Two highly penetrant mutations are described (POLE p.Leu424Val and POLD1 p.Ser478Asn) [25]. Individuals with germline POLE mutations exhibit colonic oligopolyposis (generally between 5-70 adenomas) as early as 20 years of age, CRCs, and duodenal adenomas and carcinomas. POLD1 mutation carriers exhibit colonic oligopolyposis (generally 3-50 adenomas) and CRC as young as 20 years of age as well, but in addition exhibit increased risk for endometrial cancers and brain tumors $[19,25]$. Although CRCs from PPAP patients are hypermutated or ultramutated due to loss of polymerase function these tumors are microsatellite stable and do not exhibit loss of expression of MMR proteins [10,25].

The opportunity to prevent the occurrence of and mortality from hereditary colorectal cancer is maximized by the recognition of clinical features of each syndrome, an accurate risk assessment with genetic testing and appropriate screening and surveillance. Collaboration between primary care providers, gastroenterologists, colorectal and other surgeons, pathologists, oncologists, and genetic specialists is the optimal approach to care for patients and families with hereditary colorectal cancer [23].

Modern molecular platforms give the ability to characterize tumors at multiple levels and to define molecular and biological subtypes of cancer. Cancers could be divided into subtypes that are more or less aggressive. Identification of a more aggressive subtype may influence the type of their treatment. Molecular stratification and sub classification of tumors will add a step to traditional clinical practice and better diagnosis and therapy of different types of cancer as well as colorectal cancer [26].

Optimization of molecular genetic testing to predict the risk for developing cancer, to diagnose a disease at an early stage, to give a prognosis, and predict treatment response is of great importance to the patients as well as to the health professionals. 


\section{References}

[1] Kinzler, KW, Vogelstein B. Lessons from hereditary colorectal cancer. Cell. 1996; 87: 159-70.

[2] Vogelstein B, Kinzler KW. Cancer genes and the pathways they control. Nat Med. 2004;10:789-99. doi:10.1038/nm1087

[3] Carethers JM, Jung BH. Genetics and genetic biomarkers in sporadic colorectal cancer. Gastroenterology. 2015;149:1177-90. doi: 10.1053/j.gastro.2015.06.047

[4] Stoffel EM, Boland CR. Genetics and genetic testing in hereditary colorectal cancer. Gastroenterology. 2015;149:1191-203. doi: 10.1053/j.gastro.2015.07.021

[5] Migliore L, Migheli F, Spisni R, Coppede F. Genetics, cytogenetics and epigenetics of colorectal cancer. J Biomed Biotech. 2011; Article ID 792362. doi:10.1155/2011/792362

[6] Jasperson KW, Tuohy TM, Neklason DW, Burt RW. Hereditary and familial colon cancer. Gastroenterology. 2010;138:2044-58. doi: 10.1053/j.gastro.2010.01.054.

[7] Fearon ER, Vogelstein B. A genetic model for colorectal tumorigenesis. Cell. 1990;61: 759-67.

[8] Berg M, Soreide K. Genetic and epigenetic traits as biomarkers in colorectal cancer. Int J Mol Sci. 2011;12:9426-39. doi:10.3390/ijms12129426

[9] Pritchard CC, Grady WM. Colorectal cancer molecular biology moves into clinical practice. Gut. 2011;60:116-29. doi: 10.1136/gut.2009.206250.

[10] Cancer Genome Atlas Network. Comprehensive molecular characterization of human colon and rectal cancer. Nature. 2012;487:330-7. doi:10.1038/nature11252

[11] Fearon ER. Molecular genetics of colorectal cancer. Annu Rev Pathol. 2011; 6:479-507. doi: 10.1146/annurev-pathol-011110-130235.

[12] Grady WM, Carethers JM. Genomic and epigenetic instability in colorectal pathogenesis. Gastroenterology.2008; 135:1079-1099. doi:10.1053/j.gastro.2008.07.076

[13] Galon J, Costes A, Sanchez-Cabo F, Kirilovsky A, Mlecnik B, Lagorce-pages C, Tosolini M, Camus M, Berger A, Wind P, Zinzindohoue F, Bruneval P, Cugnenc P-H, Trajanoski $\mathrm{Z}$, Fridman W-H, Pages F. Type, density, and location of immune cells within human colorectal tumors predict clinical outcome. Science. 2006;313:1960-4. doi: 10.1126/science.1129139

[14] Carethers JM, Koi M, Tseng-Rogenski SS. EMAST is a form of microsatellite instability that is initiated by inflammation and modulates colorectal cancer progression. Genes. 2015;6:185-205. doi: 10.3390/genes6020185

[15] Deveraj B, Lee A, Cabrera BL, Miyami K, Luo L, Ramamoorthy S, Keku T, Sandler RS, McGuire KL, Carethers JM. Relationship of EMAST and microsatellite instability among patients with rectal cancer. J Gastrointestin Surg. 2010;14:1521-8. Doi: 10.1007/s11605010-1340-6

[16] Garcia M, Choi C, Kim HR, Daoud Y, Toiyama Y, Takahashi M, Goel A, Boland CR, Koi M. Association between recurrent metastasis from stage II and III primary colorectal tumors and moderate microsatellite instability. Gastroenterology. 2012; 143:48-50. doi: 10.1053/j.gastro.2012.03.034 
[17] Cohen SA, Leininger A. The geetic basis of Lynch syndrome and its implications for clinical practice and risk management. Appl Clin Genet. 2014;7:147-58. doi: 10.2147/TACG. S51483

[18] Stoffel EM, Kastrinos F. Familial colorectal cancer, beyond Lynch syndrome. Clin Gastroenterol Hepatol. 2014;12:1059-68. doi: 10.1016/j.cgh.2013.08.015

[19] Carethers JM, Stoffel EM. Lynch syndrome and Lynch syndrome mimics: The growing complex landscape of hereditary colon cancer. World J Gastroenterol. 2015;21:9253-61. doi: 10.3748/wjg.v21.i31.9253

[20] Boland CR, Thibodeau SN, Hamilton SR, Sidransky D, Eshelman JR, Burt RW, Meltzer SJ, Rodriguez-Bigas MA, Fodde R, Ranzani GN, Srivastava S. A National cancer Institute Workshop on Microsatellite Instability for cancer detection and familial predisposition: development of international criteria for the determination of microsatellite instability in colorectal cancer. Cancer Res. 1998;58:5248-57.

[21] Umar A, Boland CR, Terdiman JP, Syngal S, de Chapelle A, Rushoff J, Fishel R, Lindor NM, Burgart LJ, Hamelin R, Hamilton SR, Hiatt RA, Jass J, Lindblom A, Lynch HT, Peltomaki P, Ramsey SD, Rodriguez-Bigas MA, Vasen HF, Hawk ET, Barrett JC, Freedman AN, Srivastava S. Revised Bethesda guidelines for hereditary nonpolyposis colorectal cancer (Lynch syndrome) and microsatellite instability. J Natl Cancer Inst. 2004;96:261-8. doi: 10.1093/jnci/djh034

[22] Heinimann K. Toward a molecular classification of colorectal cancer: the role of microsatellite instability status. Frontiers Oncol. 2013;3:272. doi:10.3389/fonc.2013.00272

[23] Macaron C, Leach BH, Burke CA. Hereditary colorectal cancer syndromes and genetic testing. J Surg Oncol. 2015;111:103-11. doi: 10.1002/jso.23706

[24] Rodriguez-Soler M, Parez-Carbonell L, Guarinos C, Zapater P, Castillejo A, Barbera VM, Juarez M, Bessa X, Xicola RM, Clofent J, Bujanda L, Balaguer F, Rene JM, de Castro L, Marin-Gabriel JC, Lanas A, Cubiella J, Nicolas-Perez D, Brea-Fernandez A, Castellvi-Bel S, Alenda C, Ruiz-Ponte C, Carracedo A, Castells A, Andreu M, Lior X, Soto JL, Paya A, Jover R. Risk of cancer in cases of suspected Lynch syndrome without germline mutation. Gastroenterology. 2013;144:926-32. doi:10.1053/j.gastro.2013.01.044

[25] Palles C, Cazier JB, Howarth KM, Domingo E, Jones AM, Broderick P, Kemp Z, Spain SL, Guarino E, Salguero I, Sherborne A, Chubb D, Carvajal-Carmona LG, Ma Y, Kaur K, Dobbins S, Barclay E, Gorman M, Martin L, Kovac MB, Humphray S, Lucassen A, Holmes CC, Bentley D, Donnelly P, Taylor J, Petridis C, Roylance R, Sawyer EJ, Kerr DJ, Clark S, Grimes J, Kearsey SE, Thomas HJ, McVean G, Houlston RS, Tomlinson I. Germline mutations affecting the proofreading domains of POLE and POLD1 predispose to colorectal adenomas and carcinomas. Nat Genet. 2013;45:136-44. doi:10.1038/ng.2503

[26] Ogino S, Fuchs CS, Giovannucci E. How many molecular subtypes. Implications of the unique tumor principle in personalized medicine. Expert Rev Mol Diagn. 2012;12:621-8. doi: 10.1586/erm.12.46 
Sažetak

\section{Molekularna stratifikacija sporadičnog i nasljednog kolorektalnog karcinoma}

Kolorektalni karcinom je jedan od najčešćih zloćudnih tumora i jedan od vodećih uzroka smrti od raka u zemljama razvijenog svijeta. Bolest nastaje kroz duži niz godina tijekom kojih kao posljedica mutacija u onkogenima, tumor supresorskim genima i genima za popravak DNA iz normalne sluznice kolona preko adenoma nastaje zloćudni metastatski karcinom. Najveći broj karcinoma kolorektuma javlja se u sporadičnom obliku dok jedna trećina bolesnika ima pozitivnu obiteljsku anamnezu i izložena je povećanom riziku da oboli od ovog zloćudnog tumora. Međutim, svega 5\% karcinoma kolorektuma nastaje kao posljedica nasljedne mutacije u genu APC ili genima za popravak krivo sparenih baza u DNA (MMR). Najčešći nasljedni sindrom karcinoma kolorektuma je sindrom Lynch (LS) koji se nasljeđuje mutacijama u genima za popravak DNA. Pojam nasljednog nepolipoznog karcinoma kolorektuma (HNPCC) koji se koristio kao sinonim za LS danas se povezuje sa spektrom obiteljskih karcinoma kolorektuma koji imaju kliničke karakteristike slične LS, ali oboljeli nisu nosioci nasljednih mutacija MMR gena. Razlikovanje nasljednih sindroma objedinjenih pod nazivom HNPCC važno je za kliničare radi pravilnog praćenja oboljelih i članova njihovih obitelji jer se isti razlikuju i po sklonosti razvoju karcinoma kolorektuma.

$U$ ovom kratkom preglednom radu opisane su molekularno genetičke promjene u sporadičnom i nasljednom kolorektalnom karcinomu te molekularna stratifikacija ovog zloćudnog tumora s obzirom na nasljednost, stečene mutacije i mikrosatelitnu nestabilnost.

Ključne riječi: karcinom kolorektuma; sporadični; nasljedni; mikrosatelitna nestabilnost.

Corresponding author:

Sanja Kapitanović

e-mail: kapitan@irb.hr 
